\title{
PERAN KELUARGA DALAM PENCEGAHAN WABAH COVID-19
}

\author{
Yuliati \\ Prodi NERS, Fakultas Ilmu Kesehatan, Universitas Esa Unggul, Jakarta \\ Jalan Arjuna Utara Nomor 9, Kebon Jeruk, Jakarta Barat - 11510 \\ yuliati@esaunggul.ac.id
}

\begin{abstract}
COVID-19 is a contagious disease that can be transmitted from people who carry the virus to other people who are susceptible to infection. One of the roles of nurses is to become an educator in the community in the campus environment in helping to prevent the transmission of Covid-19. The government continues to work to break the chain of the Covid-19 outbreak. This educational activity featured a discussion that provided an explanation of the role of the family in preventing the transmission of the "Covid-19" outbreak. This activity uses the method of providing education with reference to the prevention of covid-19 transmission based on literature studies. The data obtained in this paper is based on searching data through documents. The results of the activity show that by carrying out the role optimally and well, the family can prevent its members from the spread of the Covid-19 outbreak. The role of the family is important and at the forefront of breaking the chain from the spread of the Covid-19 outbreak. Education to the campus community which is the basis of the family that determines success in building new habits among family members. "We do prevention not because we are ordered by the institution where we work, but we do it because it is our full awareness to be safe from COVID-19. Educational programs for the campus community in building new habits must be continuous. This is our effort as members of the community to stop the spread of COVID-19 which is still happening until now,
\end{abstract}

Keywords: role, family, covid 19

\begin{abstract}
Abstrak
COVID-19 merupakan penyakit menular yang dapat menular dari orang yang membawa virusnya kepada orang lain yang rentan untuk tertular. Salah satu peran perawat adalah menjadi edukator pada masyarakat dilingkungan kampus dalam membantu melakukan pencegahan penularan wabag covid-19. Pemerintah terus berupaya guna memutus mata rantai dari wabah Covid-19. Kegiatan edukasi ini menampilkan diskusi yang memberikan penjelasan mengenai peran keluarga dalam melakukan pencegahan penularan wabah "Covid-19". Kegiatan ini menggunakan metode pemberian edukasi dengan mengacu pada pencegahan penularan covid-19 berdasarkan studi pustaka. Data yang diperoleh dalam makalah ini didasarkan pada pencarian data melalui dokumen-dokumen. Hasil kegiatan menunjukkan bahwa dengan menjalankan peran secara optimal dan baik, maka keluarga dapat mencegah para anggotanya dari persebaran wabah Covid-19. Peran keluarga menjadi penting dan garda terdepan untuk memutus mata rantai dari penyebaran wabah covid-19. Edukasi kepada masyarakat kampus yang merupakan basis keluarga yang menentukan keberhasilan untuk membangun kebiasan baru di antara anggota keluarga. "Kita melakukan pencegahan bukan karena diperintahkan oleh institusi tempat kerja kita, tapi kita melakukan karena sepenuhnya adalah kesadaran kita karena untuk aman dari COVID-19. Program edukasi untuk masyarakat kampus dalam membangun kebiasaan baru harus terus menerus. Inilah upaya kita sebagai anggota masyarakat untuk menghentikan penyebaran COVID-19 yang sampai saat ini masih terus terjadi,
\end{abstract}

Kata kunci : peran, keluarga, covid 19

\section{Pendahuluan}

Pada akhir tahun 2019, dunia dihebohkan dengan teridentifikasinya virus baru yang muncul di Kota Wuhan Cina. Virus yang dikenal dengan sebutan Severe acute respiratory syndrome-related coronavirus-2 (SARS-CoV-2) atau Coronavirus Disease 2019 (Covid-19) ini telah menyebar keberbagai negara, termasuk Indonesia. Mewabahnya virus Covid-19 yang telah banyak merenggut jiwa ini muncul diakibatkan oleh peristiwa zoonosis (perpindahan virus dari hewan ke manusia) (Erlina Burhan, 2020). Karenanya, pada tanggal 11 Maret 2020 Organisasi Kesehatan Dunia (WHO) sebagai bada kesehatan dunia menetapkan sebagai pandemi Covid-19.

Secara umum, sebagaimana dijelaskan oleh WHO Covid-19 merupakan sekumpulan virus dari subfamily Orthocronavirinae dalam keluarga Coronaviridae dan ordo Nidovirales yang menyebabkan penyakit mulai dari gejala ringan 
sampai berat. Seperti wabah serupa yang pernah terjadi sebelumnya yaitu Severe acute respiratory syndrome-related coronavirus (SARS-CoV) 2003 dan Middle East respiratory syndrome-related coronavirus (MERS-CoV) 2012( Yuliana, 2020). Ketiga jenis Corona virus tersebut semuannya bersumber dari virus yang sering ditemukan menginfeksi binatang dan kemudian bisa menyebar ke manusia, namun jenis binatangnya berbeda-beda. Misalnya, dalam kasus SARS-CoV ditularkan dari musang ke manusia, MERS-CoV ditularkan dari unta ke manusia dan Covid-19 diduga ditularkan dari ular dan kekelawar (Universitas Indonesia, 2020). Sebab itu, Covid-19 merupakan jenis virus baru yang belum pernah diidentifikasi sebelumnya pada manusia. Pada umumnya, tanda dan gejala dari infeksi coronavirus ini diantaranya ialah batuk, demam dan sesak napas, serta beberapa kasus yang berat dapat menyebabkan syndrome pernapasan akut (mengalami kesulitan bernapas) bahkan dapat menyebabkan kematian (Nur Sholikah Putri Suni, 2020).

Menurut Centers for Disease Control and Prevention (CDC), gejala Covid-19 dapat muncul atau diketahui dalam waktu 2-14 hari setelah seseorang terjangkit dengan virus tersebut. Hal ini didasarkan pada masa inkubasi dari kasus virus MERS-CoV. Lebih lanjut, CDC menjelaskan bahwa dalam penyebarannya Covid-19 ini dapat terjadi melalui kontak dekat (sekitar 2 meter) dari orang ke orang melalui cipratan pernapasan yang terjadi ketika orang yang terinfeksi Covid-19 batuk atau bersin. Cipratan dari batuk atau bersin tersebut kemudian mendarat di mulut atau hidung orang yang berada didekatnya. Selain itu, penularannya juga dapat disebabkan oleh sentuhan benda yang terdapat Covid-19, kemudian orang tersebut menyentuh hidung, mata atau mulutnya. Dalam hal ini, belum dapat dipastikan apakah seorang tersebut terinfeksi Covid-19 atau tidak. (Centers for Disease Control and Prevention, 2020). Oleh karena itu, dalam mencegah terjadinya penyebaran virus yang dapat menular dari manusia ke manusia ini, maka pemerintah Indonesia menerapkan salah satu kebijakannya yaitu social distancing melalui Work from Home (WFH) dengan maksud untuk belajar, bekerja dan beribadah di rumah. ${ }^{7}$ Kebijakan WFH ini dirasa perlu, karena dengan begitu penyebaran Covid-19 dari manusia ke manusia ini dapat terputus.

Dengan adanya kebijakan WFH ini, yang disarankan oleh pemerintah dan tenaga medis, mengindikasikan bahwa keluarga mempunyai peran penting dalam mencegah terjadinya penyebaran Covid-19. Melalui WFH, selain bertujuan untuk social distancing juga bertujuan untuk memperhatikan, mengingatkan atau membiasakan para anggota keluarganya untuk menerapkan gaya hidup sehat agar terhindar dari berbagai penyakit, khusunya dalam hal ini Covid-19. Disisi lain, disadari atau tidak penerapan WFH ini juga menjadi momentum untuk berkumpul kembali dengan keluarga dalam waktu yang lebih. Tidak seperti sebelum-sebelumnya, hanya memiliki sedikit waktu untuk berkumpul dengan keluarga yang disebabkan banyaknya waktu yang dihabiskan untuk beraktifitas di luar rumah.

Berdasarkan fenomena tersebut, kegiatan ini bertujuan memberikan edukasi dan diskusi pentingnya peran keluarga dalam mencegah persebaran wabah Covid-19. Hal ini disebabkan, penulis berasumsi bahwa keluarga memiliki peran yang sangat penting dalam membantu upaya pemerintah dalam memutus mata rantai persebaran Covid-19. Oleh karenanya, dibutuhkan kesadaran secara kolektif baik dari pemerintah maupun keluarga dalam mencegah persebaran Covid-19 tersebut. Sehingga bangsa Indonesia mampu mengalahkan atau melawan pandemi Covid-19 ini. Dosen merupakan bagian dari keluraga/ masyarakat yang mempunyai peranan penting membantu pemerintah melalui kepemimpinanya dalam keluara untuk mengajak anggota keluarganya melakukan pencegahan penyebaran virus covid-19.

\section{Metode Pelaksanaan}

Pelaksanaan edukasi dikoordinir oleh LPPM bekerja sama dengam Tim Abdimas Prodi Ners.Kegiatan dilakukan dalam bentuk FID (Forum Ilmiah Dosen).

3 tahap :

Kegiatan Abdimas ini dilaksanakan dalam

1. Tahap Pertama : Perencanaan dan Persiapan Melakukan penelusuran data dan kepustakaan tentang pencegahan penularan wabah-covid 19 berdasarkan evidence Base untuk mengidentifikasi permasalahan penularan wabah covid-19.

2. Tahap Kedua : Pelaksanaan Kegiatan.

Program edukasi dilaksanakan melalui Metode "Daring". Hasil proses pengabdian masyarakat ini mampu memberikan peningkatan pemahaman dosen sebagai anggota masyarakat dan keluarga tentang pentingnya peran keluarga dalam pencegahan penularan wabah "Covid-19". Nara sumber Yuliati dan Moderator Anita Soekarno.

\section{Hasil dan Pembahasan \\ Urgensi Keluarga dalam Bidang Kesehatan}

Keluarga merupakan unit terkecil dari masyarakat yang memiliki pengaruh kuat terhadap 
perkembangan anggota keluarganya. Adanya hubungan keluarga yang baik, juga akan membantu para anggota keluarganya dalam menghadapi setiap problem yang ada, termasuk bidang kesehatan. Dalam bidang kesehatan, Keluarga dapat didefinisikan sebagai unit dasar dalam masyarakat yang dapat menimbulkan, mencegah, mengabaikan, memperbaiki dan mempengaruhi anggota keluarga untuk meningkatkan kualitas kesehatan keluarga. ${ }^{17}$ Dengan ungkapan lain, keluarga dapat diimplifikasikan sebagai konteks sosial primer dalam mempromosikan kesehatan dan pencegahan penyakit. (Potter, Perry. (2005).

Berdasarkan definisi keluarga dalam bidang kesehatan di atas, menunjukkan bahwa setiap keluarga memiliki fungsi untuk meningkatkan kualitas kesehatan para anggota keluarganya. Fungsi keluarga menjadi modal yang sangat penting, karena keluarga merupakan unit dasar yang melaksanakan perawatan kesehatan untuk anggota keluarganya. (Mubarok, 2009). Lebih lanjut, Friedman memaparkan salah satu fungsi keluarga yang berkaitan dengan kesehatan yaitu, fungsi perawatan kesehatan (the health carre function). Fungsi ini bertujuan untuk mempertahankan keadaan kesehatan anggota keluarga, fungsi perawatan kesehatan ini bukan hanya fungsi esensial dan dasar dalam keluarga untuk mempertahankan status kesehatan anggota keluarga. Keluarga memberikan perawatan kesehatan yang bersifat preventif dan secara bersama-sama merawat anggota keluarga yang sakit.( Mubarok,2009).

Masih pada fungsi kesehatan, Bailon dan Maglaya dalam Mubarak juga memaparkan tentang fungsi keluarga dibidang kesehatan yang perlu dipahami dan dilakukan, diantaranya ialah: Pertama, mengenal masalah kesehatan setiap anggotanya. Maksudnya adalah keluarga diharapkan mampu mengenal fakta-fakta dari masalah kesehatan terhadap anggota keluarganya. Kesehatan merupakan kebutuhan keluarga yang tidak boleh diabaikan karena tanpa kesehatan segala sesuatu tidak akan berarti. Karenanya, orang tua perlu mengenal keadaan kesehatan dan perubahanperubahan yang dialami anggota keluarganya.

Kedua, mengambil keputusan mengenai tindakan kesehatan yang tepat. Fungsi ini merupakan upaya keluarga yang utama untuk mencari pertolongan yang tepat sesuai dengan keadaan keluarga, dengan pertimbangan siapa diantara keluarga yang mempunyai kemampuan memutuskan untuk menentukan tindakan keluarga. tindakan kesehatan yang dilakukan oleh keluarga diharapkan tepat agar masalah kesehatan dapat dikurangi atau bahkan teratasi.

Ketiga, merawat anggota keluarga yang mengalami masalah kesehatan. Perawatan anggota keluarga dapat dilakukan dengan mengetahui keadaan penyakitnya, mengetahui sumber-sumber yang ada dalam keluarga, mengetahui keberadaan fasilitas yang diperlukan untuk perawatan dan sikap keluarga terhadap anggotanya yang sedang sakit. Perawatan keluarga dengan melakukan perawatan sederhana tersebut dilakukan sesuai dengan kemampuannya.

Keempat, modifikasi lingkungan fisik dan psikologis. Pemodifikasian lingkungan dapat membantu keluarga melakukan perawatan pada anggota keluarga yang mengalami masalah kesehatan. Misalnya, kebersihan rumah dan menciptakan kenyamanan agar para anggota keluarga dapat beristirahat dengan tenang tanpa ada gangguan dari luar. Kelima, menggunakan fasilitas kesehatan yang ada di sekitar keluarga. Pemahaman keluarga mengenai lima tugas kesehatan tersebut merupakan aspek penting bagi keluarga dalam menjalankan fungsi-fungsi kesehatannya, dengan tujuan untuk meningkatkan kualitas status kesehatan anggota keluarganya. Begitu pentingnya peran keluarga dalam meningkatkan kualitas hidup sehat, sampai-sampai pemerintah menelurkan pedoman penyelenggaraan program Indonesia sehat dengan pendekatan keluarga. Pedoman tersebut dimaksudkan untuk meningkatkan derajat kesehatan melalui upaya kesehatan dan pemberdayaan masyarakat dengan dukungan finansial dan pemerataan layanan kesehatan.

Oleh karenanya, keluarga mempunyai peran yang sangat penting dalam mengembangkan, mencegah dan memperbaiki masalah kesehatan yang terdapat dalam anggota keluarga itu sendiri. Masalah kesehatan dalam keluarga saling berkaitan dan saling mempengaruhi antar anggota keluarga yang pada akhirnya akan mempengaruhi juga masyarakat yang ada disekitarnya. Sebab itu, keluarga memiliki posisi yang strategis untuk dijadikan sebagai bagian dari unit pelayanan kesehatan. Sebagaimana yang dipaparkan oleh Susi Oktowaty dalam penelitiannya, bahwa keluarga memiliki hubungan yang bermakna dengan kualitas hidup, baik dari aspek kesehatan fisik, psikologis dan hubungan sosial dengan lingkungan sekitarnya. (Susi Oktowaty, 2018). Dengan demikian, mengindikasikan bahwa keluarga mempunyai hubungan komplementer dengan kesehatan terhadap para anggota keluarganya dalam membangun gaya hidup sehat dan mencegah segala bentuk penyakit. Karenanya, menjadi suatu yang urgen bagi keluarga untuk memperhatikan bidang kesehatan bagi para anggotanya, apalagi di tengah pandemi Covid-19 seperti ini menjadi suatu keniscayaan bagi seluruh anggota keluarga dalam memelihara kesehatannya. 


\section{Manuver Peran Keluarga dalam Mencegah Pandemi Covid-19}

Sebagaimana disinggung sebelumnya, bahwa dunia saat ini sedang menghadapi pandemi Covid-19. Di Indonesia, awal mula munculnya Covid-19 terjadi pada 2 Maret 2020 di Depok Jawa Barat, hingga 17 April 2020 telah terkonfirmasi sebanyak 5,923 kasus positif Covid-19 dengan 607 diantaranya sembuh dan 520 kasus meninggal (Susi Oktowaty, 2018). Banyaknya jumlah kematian akibat Covid-19 tersebut, menjadikan Indonesia sebagai negara dengan tingkat kematian tertinggi di Asia Tenggara. ${ }^{24} \mathrm{Hal}$ ini tentunya mengharuskan kita untuk lebih meningkatkan kewaspadaan secara kolektif untuk mencegah penyebaran dari wabah tersebut.

Pada kenyataannya, penyebaran pandemi Covid-19 tidak hanya menyebabkan gejala dan penyakit fisik saja, tetapi juga memberikan dampak psikologis baik pada penderita atau masyarakat luas. Bagi penderita, dampak psikologis bisa dirasakan seperti perasaan tertekan, stress dan cemas saat didiagnosis positif Covid-19. Sedangkan untuk masyarakat luas, dapat menimbulkan perasaan tertekan, stress dan cemas dengan pemberitaan mengenai meningkatnya jumlah penderita Covid$19 .^{25}$ Kondisi seperti ini tentunya berbahaya bagi para individu, karenanya diperlukan antisipasi atau pencegahan terhadap dampak psikologis dari Covid19 ini, salah satunya melalui peran keluarga.

Keluarga memiliki peran terhadap segala bentuk yang terjadi pada anggotanya. Sebagaimana tercermin dalam teori peran, yaitu perilaku yang diharapkan dari seseorang yang mempunyai suatu status. Dengan kata lain, peran adalah individuindividu menempati kedudukan-kedudukan tertentu, maka meraka merasa bahwa setiap kedudukan yang ditempatinya tersebut dapat menimbulkan harapanharapan tertentu dari orang sekitarnya. (Rini Setiowaty, 2020). Dengan demikian, peran keluarga adalah tingkah laku spesifik yang dilakukan seseorang dalam konteks keluarga. Seirama dengan hal tersebut, dalam konteks kesehatan UndangUndang Nomor 36 Tahun 2009 tentang Kesehatan Pasal 12 menyebutkan bahwa setiap orang berkewajiban menjaga dan meningkatkan derajat kesehatan bagi orang lain yang menjadi tanggung jawabnya. Oleh sebab itu, keluaga memiliki peran untuk bertanggung jawab terhadap para anggotanya dalam hal kesehatan.

Berdasarkan peran tersebut, Keluarga dapat menjadi garda terdepan untuk melindungi para anggotanya dari serangan wabah Covid-19. Hal ini dikarenakan, selain penerapan WFH dari pemerintah, keluarga juga memiliki delapan fungsi yang bisa dilakukan untuk menghadapi dan mencegah persebaran wabah tersebut, sebagaimana dipaparkan oleh kepala Badan Kependudukan dan Keluarga Berencana Nasional (BKKBN) Harto Wardoyo, (BKKBN, 2020) diantaranya ialah: Pertama, fungsi agama, keluarga diharapkan agar memperkenalkan dan mengajak para anggotanya agar menanamkan nilai-nilai agama. Khususnya ditengah wabah saat ini, tentu sudah seyogyanya kita sebagai mahluk yang beriman agar dalam menghadapai wabah covid-19 ini kita harus tenang, tidak panik dan tentu kita semua meluruskan niat menyempurnakan ikhtiar dan selebihnya kita berdoa serta berserah diri kepada tuhan.

Kedua, fungsi sosial dan budaya, sebagai mahluk sosial dan berbudaya maka menjadi sebuah keharusan bagi para orang tua untuk mengajak kepada anggota keluarganya untuk membudayakan hidup bersih dan sehat di lingkungan keluarganya masing-masing, serta diringi juga dengan kepedulian baik kepada diri sendiri maupun kepada sesama anggota keluarganya untuk mencegah terjadinya penularan Covid-19.

Ketiga, cinta kasih, kita semua tahu bahwa keluarga memiliki fungsi yang sangat luhur, yaitu fungsi cinta kasih sesama keluarga. Sebagai wadah bersemainya kehidupan yang penuh cinta kasih lahir batin ini, maka keluarga harus punya rasa empati, memperhatikan dan juga menolong dengan ikut tanggung jawab terlebih jika ada keluarga yang dalam hal ini dicurigai atau bahkan sudah ada yang postitif mendertia infeksi covid-19.

Keempat, fungsi perlindungan, idealnya keluarga menjadi tempat berlindung yang aman dan nyaman bagi anggotanya. Karenanya, dalam rangka mencegah terjadinya penularan infeksi Covid-19, keluarga diharapkan mampu membangun dan menerapkan etika cara hubungan yang baik, saling mengingatkan kepada para anggotanya. Ketika semua keluarga taat dengan aturan dan himbauan dalam rangka mencegah penyebaran Covid-19 ini, maka kemudian anggota keluarga akan merasa aman.

Kelima, fungsi reproduksi, dalam rangka mengantisipasi penularan Covid-19, jika terdapat anggota keluarga yang rentan seperti ibu hamil, bayi dan balita, maka menjadi prioritas untuk mendapatkan perlindungan karena dapat mengancam kesehatan janin dalam kandungannya dan tentu menjadi suatu ancaman kesehatan bagi ibu dan bayinya. Oleh kerana itu, para anggota keluarga harus melindungi bersama, sehingga kita bersamasama bisa meningkatkan daya tahan tubuh para anggota keluarga khusunya yang rentan tersebut dengan memberikan nutrisi, gizi, makanan dan perlindungan yang cukup. Dengan demikian, maka 
fungsi keluarga dalam hal reproduksi untuk ibu hamil, bayi, anak-anak dan orang tua bisa berjalan dengan baik.

Keenam, fungsi pendidikan dan sosialisasi, kepada orang tua diharapkan agar dapat memberikan pelajaran yang terbaik untuk anggota keluarga dan anak-anaknya. Hal ini merupakan suatu yang penting untuk memperhatikan anggota keluarga, misalnya kalau batuk cara menutup mulutnya sudah benar atau belum, kemudian jika pakai masker apakah pemakaiannya sudah benar atau belum dan ketika menggunakan fasilitas umum serta ketika tanganya bersentuhan apakah sudah tertib mencuci tangan dengan baik. Semuanya itu adalah bagaimana cara memberikan pelajaran kepada anggota keluarga, dan tentunya menjadi tanggung jawab fungsi pendidikan dan sosialisasi bagi keluarga kepada para anggotanya.

Ketujuh, fungsi ekonomi, dalam situasi seperti ini orang tua harus mampu mengajarkan kepada anggotanya keluarganya untuk tidak boros, seperti berpergian yang tidak penting, belanja berlebihan atau yang tidak begitu diperlukan untuk saat ini. Dengan ungkapan lain, harus efisien dalam mengeluarkan finansialnya dan menahaman diri dari hal-hal yang tidak penting secara ekonomi.

Kedelapan, fungsi pembinaan lingkungan, di tengah wabah Covid-19 seperti ini tentunya menjadi sebuah keharusan bagi para individu untuk membersihkan lingkungan sekitar. Karenanya, orang tua harus mampu menanamkan dan mengajak kepada anggota keluarganya untuk menerapkan gaya hidup ramah lingkungan untuk menciptakan lingkungan yang bersih. Melihat fungsi-fungsi di atas, maka keluarga memiliki peran untuk mencegah para anggota keluarganya agar terhindar dari pandemi Covid-19. Lebih dari itu, keluarga mempunyai tujuan meningkatkan kualitas atau membangun gaya hidup sehat dan mencegah dari segala bentuk penyakit. Karena, kebiasaan yang dimiliki anggota keluarga sebagian terbentuk oleh pendidikan keluarga, mulai dari bangun tidur hingga saat akan tidur kembali.(Muhammad Abdul Halim Sidiq, 2019), Oleh karena itu, peran keluarga menempati posisi penting dan strategis dalam hal ini untuk membentuk gaya hidup sehat. Misal, dapat dimulai dari hal-hal mendasar seperti asupan makanan dan minuman, pola asuh dan mengajak para anggotanya untuk sering berolahraga.

\section{Kesimpulan}

Terjadinya wabah Covid-19 merupakan virus yang terjadi pada akhir tahun 2019, dengan penyebaranya hingga ke seluruh dunia dan telah merenggut banyak korban jiwa ini kemudian oleh WHO ditetapkan menjadi pandemi. Karenanya, tak terkecuali Indonesia, pemerintah terus berupaya untuk memutus mata rantai penyebaran Covid-19. Salah satunya yaitu, dengan menerapkan kebijakan WFH. Dengan diterapkannya WFH ini mengindikasikan bahwa keluarga memiliki peran penting dalam mencegah penyebaran Covid-19 tersebut. Hal ini dikarenakan keluarga memiliki beberapa fungsi di dalamnya. Fungsi-fungsi yang bisa dilakukan untuk menghadapai dan mencegah persebaran wabah tersebut. Disisi lain, keluarga mempunyai hubungan komplementer dengan kesehatan terhadap para anggotanya dalam membangun gaya hidup sehat dan mencegah dari segala bentuk penyakit, sebagaimana fungsi yang dimilikinya dalam meningkatkan kualitas kesehatan bagi para anggotanya. Karenanya, menjadi keniscayaan bagi keluarga untuk menjalankan fungsi- fungsi tersebut. Dengan demikian, selain upaya pemerintah yang juga fokus pada bidang kesehatan dan pemberdayaan ekonomi agar roda perekonomian terus bergerak, keluarga juga menjadi garda terdepan untuk memutus penyebaran wabah Covid-19 ini. Oleh karenanya, bergotong royong dalam menghadapi situasi seperti ini sangat diperlukan, sehingga bangsa Indonesia dapat mengalahkan wabah tersebut dan kembali seperti sediakala.

\section{Daftar Pustaka}

Akmal Taher, Yudhi Prayuda Ishak Djuarsa, dkk. (2016). Pedoman Umum Indonesia Sehat dengan Pendekatan Keluarga, Jakarta: Kementerian Kesehatan RI, hlm. 25.

Asmandi Alsa. (2004). Pendekatan Kuantitatif dan Kualitatif serta Kombinasinya dalam Penelitian Penelitian Psikologi, Yogyakarta: Pustaka Pelajar, hlm. 65.

Badan Kependudukan dan Keluarga Berencana Nasional. "BKKBN Kompak Hadapi Pandemi Korona", https://www.bkkbn.go.id/detailpost/bkkbnkompak-hadapi-pandemi-corona. Diakses pada 20 April, 2020, Pukul 14.55.

Centers for Disease Control and Prevention, "Symptoms of Novel Coronavirus (Covid19)",

https://www.cdc.gov/coronavirus/covid19/about/symptoms.html. Diakses Pada Jum'at 10 April 2020, Pukul 08.47.

Cipto Roso. (2015). "Peran Keluarga Prasejahtera dengan Upaya Pencegahan Infeksi Saluran Pernafasan Akut (ISPA) pada Balita di Desa Depok Kecamatan Kandeman Kabupaten 
Batang", FIKKeS, Volume. 8, Nomor. 2, Oktober 2015.

CNN Indonesia. "Indonesia Kini Catat Kasus Virus Corona Tertinggi di ASEAN", https://www.cnnindonesia.com/internasional /20200417170226-106-494628/indonesiakini-catat-kasus- virus-corona-tertinggi-diasean. Diakses pada 17 April 2020, Pukul 17.25 .

David Berry. (2003). Pokok-Pokok Pikiran dalam Sosiologi, Jakarta: Raja Grafindo Persada, hlm. 101.

Erlina Burhan, Fathiyah Isbaniah, dkk. (2020). Pneunomia Covid-19, Jakarta: Perhimpunan Dokter Paru Indonesia, hlm. 4.

Friedman, M. M., Bowden, V. R., \& Jones, E.G. Family Nursing, Research, Theory \& Practice, Fifth Edition. New Jersey: Pearson Education, Inc.

Gugus Tugas Percepatan Covid-19, "Data Sebaran", https://www.covid19.go.id/. Diakses pada 17 April 2020, Pukul 16.35.

Mubarak, Chayatin dan Santosa. (2009). Ilmu Keperawatan Komunitas Konsep dan Aplikasi, Jakarta: Salemba Medika, hlm. 46.

Muhammad Abdul Halim Sidiq. (2019). "Analisis Pendidikan Karakter Berbasis Keluarga", Bidayatuna, Volume. 2, Nomor. 1, April 2019, hlm. 89.

Nur Rohim Yunus, Annisa Rezki. (2020). "Kebijakan Pemberlakuan Lockdown sebagai Antisipasi Penyebaran Corona Virus Covid-19", SALAM, Volume. 7, Nomor. 3, 2020, hlm. 228.

Nur Sholikah Putri Suni. (2020). "Kesiapasiagaan Indonesia Menghadapi Potensi Penyebaran Coronavirus Disease. INFO Singkat, Volume. 12, Nomor. 3, 2020, hlm. 14.

Potter, Perry. (2005). Fundamental Keperawatan, Jakarta: Salemba Medika, hlm. 23.

Rini Setyowati. "Dampak Covid Menurut Psikolog UNS", $\quad$ https://uns.ac.id/id/unsupdate/dampak-covid-19-menurut-psikologuns.html. Diakes pada 18 April 2020, Pukul 08.22 .
Soerjono Soekanto. (2010). Sosiologi suatu Pengantar, Jakarta: Raja Grafindo Persada, hlm. 243.

Sugiyono. (2005). Memahami Penelitian Kualitatif, Bandung: Alfabeta, hlm. 64.

Suprajitno. (2004). Asuhan Keperawatan Keluarga: Aplikasi dalam Praktik, Jakarta: EGC.

Susi Oktowaty, Elsa Pudji Setiawan, Nita Arisanti. (2018). "Hubungan Fungsi Keluarga Kesehatan dengan Kualitas Hidup Pasien Penyakit Kronis Degeneratif di Fasilitas Kesehatan Tingkat Pertama”, hlm. 4.

Susi Oktowaty, Elsa Pudji Setiawan, Nita Arisanti. (2018). "Hubungan Fungsi Keluarga Kesehatan dengan Kualitas Hidup Pasien Penyakit Kronis Degeneratif di Fasilitas Kesehatan Tingkat Pertama", JKS, Volume. 4, Nomor. 1, September 2018.

Universitas

Indonesia,

https://www.ui.ac.id/pengenalan.html. Diakses Pada Kamis, 9 April 2020, Pukul 14.23.

World Health Organization, "Coronavirus", https://www.who.int/indonesia/news/novelcoronavirus/qa-for-public. Diakses Pada Minggu, 12 April 2020, Pukul 13. 55.

Yuliana. (2020). "Corona Virus Diases (Covid-19): Sebuah Tinjauan Literatur", Wellness and Healthy Magazine, Volume 2, Nomor. 1, Februari 2020.

Zaidin Ali. (2009). Pengantar Keperawatan Keluarga, Jakarta: EGC. 